\title{
Dilema Moral: Kepalsuan dan Keteladanan Komunikasi Politik di Indonesia
}

\begin{abstract}
Muhammad E. Fuady
ABSTRACT

Political activities often generate political question toward ethics or moral issues. Political world believed as moral costly and degrading political figures into somewhat vague and manipulative person in order to maintain his/her positions. The case of Amien Rais, who failed to be Indonesian president resulted from fair election, supported such assumptions. Porn-video-streaming involving important political members also provided a strong case that political domain is actually a dirty world. But, in every situation, democracy needs a fair and honest people to give a high standard performance in politics. A good political leader would leave good memories and excellent example for other political leaders who fill in the same positions in the future.
\end{abstract}

Kata kunci: moral, komunikasi politik, keteladanan politik

Apa yang akan kita lakukan bila menghadapi sebuah situasi yang sangat sulit untuk memilih? Semua alternatif tidak enak untuk dipilih. Ada konsekuensi dan risiko yang harus kita tanggung dari keputusan yang diambil. Masih untung bila di antara berbagai alternatif ada sebuah pilihan yang rasanya manis. Bagaimana bila semuanya pahit? Bagaimana bila seperti buah simalakama, bila kita makan ibu mati, tidak dimakan bapak mati. Misalnya, kita dihadapkan pada situasi darurat untuk menolong isteri atau ibu yang tenggelam di pantai. Kita tidak dapat menolong keduanya. Manakah yang akan kita pilih? Itulah dilema. Menurut Donagan (dalam MacIntyre, 2006 : 91), bila orang yang tenggelam itu bukan orang yang kita kenal, mudah saja, pilih salah satu untuk ditolong.

Meski ada pakar yang menyanggah adanya dilema moral, seperti Earl Conee dan Walter SinnottArmstrong (dalam MacIntyre, 2006: 86 : 89), fakta menunjukkan, dilema moral ini nyata ada. Sederhana saja, bila alternatif yang dipilih tidak tepat, tidak disukai, atau memiliki moral cost yang besar, dilema moral muncul berupa rasa bersalah atau penyesalan.

Dalam ilmu politik dan studi komunikasi politik, dilema moral kerap terjadi. Ini pernah Amien Rais rasakan pasca jatuhnya Soeharto. Amien Rais didaulat banyak pihak menjadi Presiden RI secara langsung, namun ia menolak dengan alasan rakyat Indonesia akan menilainya melakukan kudeta. Ia ingin naik secara elegan melalui pemilu. Memang tidak mudah bagi Amien untuk memilih saat itu, namun kini tampaknya Amien menyesal karena untuk meraih kursi RI-1 ternyata tidaklah mudah. Menurut Emha Ainun Najib, Amien telah kehilangan momentumnya. Kata Emha, seharusnya Amien tidak usah berpikir berat-berat dan susahsusah, tinggal mengiyakan, jadilah ia presiden setelah Soeharto. Sekarang semuanya hanyalah 
angin lalu. Dilema berupa konflik batin dalam diri membuat Amien mencoba memilih yang terbaik, meski berujung penyesalan pada kegagalannya meraih kursi RI -1.

Pernah pula dilema serupa menerpa Amien. Di akhir masa masih jabatannya sebagai presiden, B.J. Habibie bersama para pimpinan Golkar, Panglima TNI Wiranto, politisi dari kalangan Islam modernis dan Poros Tengah, melakukan pertemuan untuk menentukan calon presiden (capres) yang akan berhadapan dengan capres dari PDI-Perjuangan, Megawati Soekarnoputri. Mereka mendesak Amien yang telah menduduki jabatan sebagai Ketua MPR untuk maju. Sebuah tawaran yang sangat manis. Namun,Amien menolak. Pasalnya, jauh-jauh hari Amien selalu mengampanyekan K.H. Abdurrahman Wahid (Gus Dur) sebagai capres dari Poros Tengah. Di hari pertama Sidang Paripurna MPR, Amien menyebut Gus Dur sebagai "Big Brother". Lalu, Amien menegaskan, "Saya baru terpilih sebagai Ketua MPR dan selama ini saya menjual Gus Dur sebagai calon presiden. Bila saya menelikung Gus Dur sebagai calon presiden, betapa tidak konsistennya saya. Saya tidak dapat membayangkan bagaimana hubungan NU dan Muhammadiyah setelah ini."

Amien Rais pernah menyatakan bahwa politisi adalah orang yang harus mengatakan apa pun untuk meyakinkan orang lain, sementara ia sendiri tidak yakin dapat memenuhinya. Ia tidak mau seperti itu. Itu berarti menjadi politisi yang jujur tidak mudah. Menjadi politisi seperti yang selama ini ada mudah saja. Dengan kata-kata yang berbunga, janjikan sesuatu kepada konstituen. Perkara terpenuhi atau tidak, itu urusan belakangan. Itu pula dilema moral sebagai risiko yang akan dihadapi oleh politisi yang hitam putih.

Mill (dalam MacIntyre, 2006 : 114) menyatakan, landasan dari "kesejahteraan sosial" dan "peradaban" bergantung pada truthfulness. Kredibilitas diperlukan untuk mendukung kehidupan sosial. Seperti Mill, Amien Rais memiliki cita-cita yang - bisa disebut - luhur. Amien ingin merealisasikan gagasannya tentang high politics (dalam Rais, 1998 : 146). Bukan lowpolitics. Politik kualitas-tinggi versus politik kualitas-rendah. High politics diterjemahkan sebagai sebuah sikap politik adiluhung, politik luhur, dan politik berdimensi moral etis. Politik dengan landasan kejujuran dan kepercayaan. Sedangkan low politics, adalah tindakan yang dilakukan untuk mendapatkan dan mempertahankan kekuasaan. Menurut Amien, low politics memiliki persamaan dengan konsep politik Machiavelli dalam Il Principe yang membolehkan segala cara demi memperoleh kekuasaan, berbeda dengan high politics yang memandang kekuasaan sebagai amanah dari rakyat yang tidak boleh disalahgunakan dan harus dipertanggungjawabkan. Kekuasaan dalam high politics adalah nikmat yang dikaruniakan oleh Allah untuk menegakkan keadilan dan membangun kesejahteraan rakyat.

Namun, untuk mewujudkan politik adiluhung sulit. Pengalaman membuktikan, tujuan bersama dalam politik dapat diperoleh karena transaksi yang lebih menguntungkan dibandingkan aspek kejujuran dan kepercayaan. Seringkali kita pelajari ini sebagai politik dagang sapi (dalam Dan Nimmo, 1993 : 31). "Jika kamu mendukung saya, saya akan dukung kamu". Bukannya "Saya ingin tawarkan gagasan yang lebih baik kepada Anda dan kerenanya saya akan dukung gagasan itu". Tampaknya kita harus ingat adagium "Power tends to corrupt, but absolute power corrupt absolutely" dari Lord Acton (dalam Budiarjo, 1993). Kekuasaan cenderung disalahgunakan. Apalagi tidak kawan yang abadi dalam politik, yang ada hanyalah kepentingan. Siapa yang menjadi kawan hari ini, esok bisa jadi lawan. Jadi, bagaimana mau berlandaskan kejujuran dan kepercayaan bila politisi memiliki kepentingan dan cara yang berbeda. Ideologi dan tujuan partai masing-masing berbeda. Yang menyatukan mereka hanyalah kepentingan. Setelah kepentingan itu tercapai atau berubah, bubarlah kebersamaan itu. Seperti pernyataan Saifullah Yusuf beberapa minggu setelah diberhentikan dari posisinya sebagai menteri. Ia meminta DPR memanggil Presiden Susilo Bambang Yudhoyono untuk menjelaskan dukungan terhadap resolusi PBB. Saat menjadi menteri ia memberikan pernyataan tak mungkin “melawan” bosnya seperti itu. 
Dalam sebuah negara modern dan demokratis, partai politik memang merupakan sebuah instrumen penting dalam menyuarakan aspirasi rakyat. Rakyat merupakan faktor yang harus diikutsertakan dalam proses politik dan partai politik berkembang menjadi penghubung antara rakyat dengan pemerintah (dalam Budiardjo, 1993 : 160-161). Tetapi, adakah jaminan partai akan menjadi penghubung? Pengalaman menunjukkan bahwa partai sering mencederai suara msyarakat, bahkan konstituennya. Dari pemberitaan media massa, kita tahu beberapa tahun lalu, Megawati Soekarnoputri lebih memilih Soetiyoso sebagai calon Gubernur DKI Jakarta dibandingkan calon dari PDIPerjuangan sendiri, padahal itu merupakan aspirasi mayoritas dari publik PDI-P. Bahkan, calon gubernur yang disokong warga PDI-P terkena recall. Wajar saja, banyak kebijakan Mega yang tidak pas dengan aspirasi warga PDI-P di tingkat akar rumput membuat politisi senior PDI-P kecewa dan hengkang.

Lalu, di manakah keselarasan antara partai politik dengan rakyat? Kita belajar bahwa dalam negara demokratis, partai politik mempunyai beberapa fungsi (dalam Budiardjo, 1998:17), salah satunya adalah sebagai sarana komunikasi politik. Arus informasi dalam suatu negara bersifat dua arah, artinya berjalan dari atas ke bawah dan dari bawah ke atas. Kedudukan partai dalam arus ini adalah sebagai jembatan antara "mereka yang memerintah" (the rulers) dengan "mereka yang diperintah" (the ruled). Dengan demikian partai politik menyalurkan aneka ragam pendapat dan aspirasi masyarakat, dan merumuskannya dalam program partai untuk disampaikan kepada pemerintah. Di lain pihak, partai politik juga turut menyebarluaskan kebijakan-kebijakan pemerintah kepada masyarakat. Bagi masyarakat yang sering "disakiti" oleh partai, penyaluran aneka ragam aspirasi melalui partai hanya isapan jempol. Itu semua serupa dengan kepalsuan-kepalsuan yang diungkap Kant (dalam MacIntyre, 2006), "Kejujuran dan kebenaran secara universal tidak boleh dilanggar, karena itu menjadi dasar penting untuk mencapai kenyamanan hidup." Namun, para pendusta menutupinya dengan kebohongan- kebohongan. Karenanya, sebagian orang memilih "bicara" di jalanan, seperti orasi politik dan demonstrasi.

Menurut Kant, sebenarnya para pendusta mempunyai keistimewaan karena adanya konformitas untuk itu. Mereka berhasil melakukan dusta sepanjang itu dibenarkan orang lain, "Kepalsuan bagi mereka yang berhasil melakukannya adalah satu keuntungan atas diri mereka yang ditipu. Para pendusta sukses menipu kita, tidak hanya tentang isi pernyataan, tetapi juga tentang kepercayaan-kepercayaan mereka sendiri dan niat dalam diri mereka. Mereka merahasiakan niatnya dari kita, bahkan di dalam kasus yang paling sederhana dalam suatu situasi yang kompleks, pendusta tidak menyukai kenyataan. Orang-orang yang menyukai kenyataan mungkin memiliki banyak rahasia, termasuk niat-niat mereka sendiri." Bagi penganut paham moral, apa yang dilakukan pendusta sebagai "kegagalan untuk menghormati kebenaran adalah suatu kegagalan di dalam menghormati dirinya sebagai suatu makhluk berakal.

Bila ditarik ke situasi kekinian, pernyataan Kant mengenai kepalsuan dan kebenaran dapat menjadi panduan bagi komunikasi politik di Indonesia. Sebagai contoh kongkret, kita menonton, membaca, dan mendengar dari media massa tentang kasus penyalahgunaan dana nonbujeter Departemen Kelautan dan Perikanan (DKP). Terkuak fakta dan data di pengadilan yang menyeret mantan Menteri DKP, Rokhimin Dahuri, bahwa tim kampanye calon presiden di Indonesia menerima sejumlah uang dari dana nonbujeter DKP. Setiap tim kampanye memperoleh jumlah yang berbeda, mulai dari puluhan sampai ratusan juta rupiah. Yang patut diacungi jempol, Amien Rais sebagai salah satu capres mengakui pernah menerima bantuan dari Rokhimin. Meski ia tidak mengetahui legalitas cara Rokhimin mendapatkan uang tersebut. Sementara tim kampanye capres lain, seperti Megawati, Wiranto, dan Susilo Bambang Yudhoyono menyangkalnya.

Apa yang Amien lakukan menjadi pelajaran berharga bagi anak bangsa karena secara gentle dan jujur ia mengakuinya. Bahkan bila ia 
dinyatakan bersalah, ia siap dipenjara. Bila merujuk pada pendapat Kant, berkata benar berarti menjadi indikator menghormati kebenaran, dan menghormati kebenaran berarti menghormati dirinya sebagai makhluk yang berakal. Sebaliknya, berkata tidak benar berarti tidak menghormati kebenaran dan karenanya ia tidak menghargai dirinya sebagai makhluk berakal. jadi, politisi yang tidak jujur adalah politisi yang tidak berakal.

Setiap orang dalam masyarakat, sekurangkurangnya memiliki potensi untuk menjadi komunikator politik. Namun, dalam komunikasi politik, komunikator politik adalah mereka yang sedikit banyak mempengaruhi terbentuknya berbagai opini sebagai hasil dari komunikasi yang mereka lakukan. Di antaranya adalah politikus atau politisi. Politikus adalah orang yang bercita-cita untuk dan atau memegang jabatan pemerintah yang harus dan memang berkomunikasi tentang politik. Bayangkan bila mereka mengedepankan kebohongan dan kepalsuan. Akan menjadi apa dunia ini? Bila Nagabonar benar-benar ada di dunia ini, mungkin dia akan berkata "Apa kata dunia?"

Nabi Muhammad saw pernah menyatakan "Qulil Haqqo wa laukaana murron", artinya "Katakanlah kebenaran walaupun pahit." Walau tidak enak rasanya, katakan bila memang benar. Meski ada kondisi yang mengharuskan kita menutupi kebenaran, tetapi bukan bermaksud berbohong. Misalnya, menyangkut keselamatan seseorang. Bila ada orang yang akan membunuh seseorang dan bertanya kepada kita tentang keberadaan orang itu, kita harus menutupinya. Ternyata Islam mengatur ini dan selaras pula dengan pendapat banyak filusuf moralis (McIntyre, 2006).

Kita dapat memetik pelajaran dari kasus Bill Clinton. Presiden Amerika tidak boleh berbohong. Bila berbohong, risiko yang paling fatal adalah impeachment, seperti Nixon yang diberhentikan dari kedudukannya sebagai presiden. Clinton juga telibat Monicagate, atau dikenal pula dengan Zippergate. Rakyat Amerika tidak bisa menolerir Clinton yang membohongi mereka dengan mengatakan tidak berhubungan seks dengan Lewinsky. Padahal bukti telah menunjukkan Clinton melakukannya. Clinton berkilah kepada
Jaksa Agung Kenneth Star dengan menyatakan bahwa yang dilakukannya bukan hubungan seks, ia hanya melakukan oral seks dengan Lewinsky. Kebohongan Clinton memicu reaksi negatif karena menurut saksi ahli dan literatur di Amerika oral seks pun termasuk kategori hubungan seks. Saat itu polling menunjukkan rakyat Amerika ingin Clinton berhenti sebagai presiden. Hebatnya, setelah Clinton meminta maaf secara terbuka atas kebohongannya, didukung oleh Hillary yang tampil sebagai isteri yang pemaaf di depan pers dan rakyat Amerika, polling menunjukkan sebagian besar rakyat Amerika memaafkan Clinton dan tetap mendukungnya sebagai presiden.

Kita boleh mengatakan, tersebarnya tayangan video seks anggota DPR RI dengan seorang wanita pedangdut yang sempat menghebohkan jagat politik di Indonesia sangat menguntungkan publik. Kalau memang benar kabar yang beredar bahwa anggota DPR itu akan diproyeksikan sebagai Menteri Agama, kita tahu bahwa ia tidak pantas mendudukinya karena apa yang dilakukannya tidak sesuai dengan jabatan yang akan disandangnya. Namun, ada pelajaran yang dapat dipetik dalam kasus itu, yakini ia jujur atas perbuatannya. Yang tak kalah pentingnya adalah peranan sang isteri yang terus sabar mendampingi dan berani tampil di muka publik hingga kasus ini mereda. Mirip dengan Hillary yang mau memaafkan dan mendukung Clinton.

Memetik pelajaran berharga dari kasus dana nonbujeter yang menyangkut Amien Rais, Monicagate yang melibatkan Clinton, dan video seks anggota dewan, hendaknya sebagai politisi, faktor moral menjadi keutamaan. Kepalsuan dan kebohongan justru akan menoreh memori hitam sepanjang zaman. Kejujuran dan kebenaran dapat menjadi solusi standar untuk menghindarkan diri dari dilema-dilema moral. Selain itu, ada jejak langkah di dunia politik yang digelutinya. Mereka yang jujur akan dikenang sebagai politisi yang memberi pendidikan politik, sebagai contoh yang patut diteladani oleh politisi di masa kini dan akan datang. Mengutip istilah dari Novel Ali (1999), itu akan menjadi keteladanan demokrasi. 
Terakreditasi Dirjen Dikti SK No. 56/DIKTI/Kep/2005

\section{Daftar Pustaka}

Ali, Novel. 1999. Peradaban Komunikasi Politik. Bandung: Remaja Rosdakarya.

Budiardjo, Miriam. 1993. Dasar-dasar Ilmu Politik. Jakarta. Gramedia Pustaka Utama.

1998. Partisipasi dan Partai

Politik. Jakarta: Yayasan Obor Indonesia.
MacIntyre, Alasdar. 2006. Ethics and Politics. New York: Cambridge University Press.

Nimmo, Dan. 1993. Komunikasi Politik: Komunikator, Pesan dan Media. Bandung: Remaja Rosdakarya.

Rais, M. Amien. 1998. Membangun Politik Adiluhung. Bandung: Zaman Wacana Mulia. 
